\title{
Bioaccumulation of trace metals in aquatic food web. A case study, Liaodong Bay, NE China
}

\author{
Artur Radomyski $^{\mathrm{a}}$, Kai Lei ${ }^{\mathrm{b}}$, Elisa Giubilato ${ }^{\mathrm{a}}$, Andrea Critto $^{\mathrm{a}, *}$, Chunye Lin $^{\mathrm{b}, *}$, Antonio Marcomini ${ }^{\mathrm{a}}$ \\ ${ }^{\text {a }}$ Department of Environmental Sciences, Informatics and Statistics, University Ca' Foscari Venice, Via Torino 155, Mestre, 30172 Venice, Italy \\ ${ }^{\mathrm{b}}$ State Key Joint Laboratory of Environmental Simulation and Pollution Control, School of Environment, Beijing Normal University, 100875 Beijing, People's Republic of \\ China
}

\section{A R T I C L E I N F O}

\section{Keywords:}

Ecological exposure assessment

Metal bioaccumulation

Sensitivity analysis

\begin{abstract}
A B S T R A C T
The recently developed modelling tool MERLIN-Expo was applied to support the exposure assessment of an aquatic food web to trace metals in a coastal environment. The exposure scenario, built on the data from Daliao River estuary in the Liaodong Bay (Bohai Sea, China), affected by long-term and large-scale industrial activities as well as rapid urbanization in Liao River watershed, represents an interesting case-study for ecological exposure modelling due to the availability of local data on metal concentrations in water and sediment. The bioaccumulation of selected trace metals in aquatic organisms was modelled and compared with field data from local aquatic organisms. Both model results and experimental data demonstrated that $\mathrm{As}, \mathrm{Cd}, \mathrm{Cu}, \mathrm{Ni}, \mathrm{Pb}$ and $\mathrm{Zn}$, out of examined metals, were accumulated most abundantly by invertebrates and less by higher trophic level species. The body parts of the sampled animals with the highest measured concentration of metals were predominantly muscles, intestine and liver and fish skin in the case of $\mathrm{Cr}$.

The Morris and extended Fourier Analysis (EFAST) were used to account for variability in selected parameters of the bioaccumulation model. Food assimilation efficiency and slopes and intercepts of two sub-models for calculating metal specific BCFs $\left(\mathrm{BCF}_{\text {metal }}\right.$-exposure concentration) and fish weight $\left(\mathrm{Weight}_{\text {fish }}\right.$-Length fish $_{\text {fise }}$ ) identified as the most influential parameters on ecological exposure to selected metals.
\end{abstract}

\section{Introduction}

It is well known that trace metals including metals and metalloids are released from both natural and anthropogenic sources and pose potential risks to ecosystem and human health due to their accumulation in food webs. Human sources of pollutants including metals are numerous as a consequence of rapid urbanization and industrialization over the last century. The coastal and estuarine ecosystems in China are now facing increasing metal pollution stress because metals released along with municipal and industrial wastes may enter the sea by river transportation, and ultimately accumulate in the coastal areas, introducing long-term accumulative effects (Pan and Wang, 2012). Northeastern China coastal regions, such as Bohai Sea, are considered to be the most affected by metal contamination (Gao and Chen, 2012). More importantly, metals can be taken up by marine organisms, entering the food chain and be potentially transferred to the upper trophic levels, which can eventually lead to adverse effects on humans due to the consumption of contaminated seafood (Szefer, 2013). Currently, there is a very serious concern for seafood safety originating from accumulation of metals and organic pollutants (Liu et al., 2015; Hu et al., 2016; Rodríguez-Hernández et al., 2016; Tong et al., 2017) as well as from threats that just recently have been gaining proper attention such as plastics and microplastics (Oksman, 2016, EFSA Panel on Contaminants in the Food Chain (CONTAM), 2016; Peng et al., 2017), which require deepening the understanding about contaminants bioaccumulation in food chains (Koelmans, 2015). The transfer of contaminants from abiotic environment to a specific food product is of importance regarding the quality and safety of food and has been recognised by international regulatory bodies, such as the European Commission (EC) of European Union (EU) which has set up safety maximum levels for several contaminants in certain foodstuffs including fish and seafood (EC No 1881/2006). However, currently in the EU the available limits are established only for few metals; maximum Cd concentration levels in muscle meat of fishes varies between species from $0.1 \mathrm{mg} / \mathrm{kg}$ fw in sea bream, grey mullet or sardines to $0.3 \mathrm{mg} / \mathrm{kg}$ $\mathrm{fw}$ for anchovy and swordfish, $0.5 \mathrm{mg} / \mathrm{kg}$ fw for crustaceans and $1.0 \mathrm{mg} / \mathrm{kg}$ fw for bivalve mollusks and cephalopods. Similarly, maximum concentration levels for $\mathrm{Pb}$ are set to $0.3 \mathrm{mg} / \mathrm{kg}$ fw for fish,

\footnotetext{
* Corresponding authors.

E-mail addresses: critto@unive.it (A. Critto), c.lin@bnu.edu.cn (C. Lin).
} 


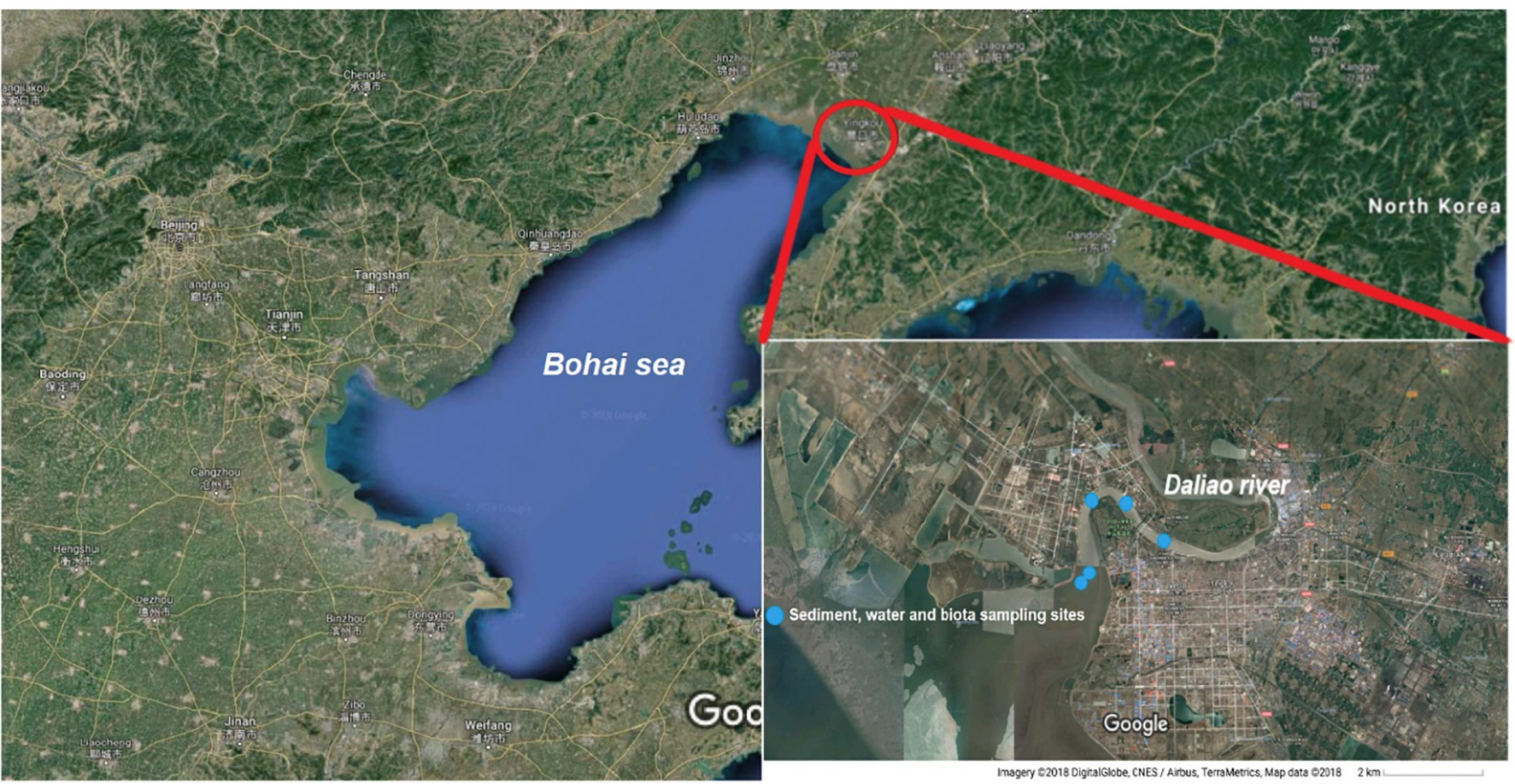

Imagery @2018 Data SIO, NOAA, U.S. Navy, NGA, GEBCO, Landsat / Copernicus, Map data @2018 Google, SK telecom 50 km I

Fig. 1. Study area and sampling locations of sediments, water and biota in the lower stretch of the Daliao River.

$0.5 \mathrm{mg} / \mathrm{kg}$ fw for crustaceans (both pertaining to muscles), and $1.5 \mathrm{mg}$ / $\mathrm{kg}$ fw for bivalve molluscs. $\mathrm{Hg}$ maximum level was fixed at $0.5 \mathrm{mg} / \mathrm{kg}$ $\mathrm{fw}$ for fishery products and muscle meat of fish and $1.0 \mathrm{mg} / \mathrm{kg}$ fw for number of fish species including mullet, swordfish and tuna (EC No 1881/2006)). Similarly, China also promulgated the National Food Safety Standard (National food safety standards in food contaminants. The State Standard of the People's Republic of China, GB 2762-2017), and the Maximum Limit Concentrations (MLC) that are $0.5 \mathrm{mg} / \mathrm{kg} \mathrm{fw}$ for $\mathrm{Pb}$ in fish and crustaceans, and $1.5 \mathrm{mg} / \mathrm{kg}$ fw in bivalve molluscs; for Cd, MLC is set at $0.1,0.5$ and $2.0 \mathrm{mg} / \mathrm{kg}$ fw for fish, crustaceans and bivalves respectively, while MLC for As and $\mathrm{Hg}$ in aquatic animals and their products is set at $0.5 \mathrm{mg} / \mathrm{kg}$ fw and $1.0 \mathrm{mg} / \mathrm{kg} \mathrm{fw}$ in fish and their products, and for $\mathrm{Cr}$ there is a $2.0 \mathrm{mg} / \mathrm{kg} \mathrm{fw}$ limit in aquatic animals and their products.

Aquaculture global production rose to 73.8 million tonnes in 2014, a third of which comprised molluscs, crustaceans and other non-fish animals, with China remaining the leading nation for aquaculture (FAO, 2016). Asian countries alone account for some $91 \%$ of the global production of molluscs and 70\% of global aquaculture production (Li et al., 2011). The domestic demand for seafood in China has increased dramatically from an annual consumption of $7 \mathrm{~kg}$ per person in 1985 to about $25 \mathrm{~kg}$ in 2005 and $37.9 \mathrm{~kg}$ in 2013 (Fabinyi, 2016; FAO, 2016). China currently consumes $37 \%$ of global production of seafood and aquatic products, reaching seafood consumption per capita $44 \mathrm{~kg}$ - estimated to increase to $50 \mathrm{~kg}$ by 2026 (OECD/FAO, 2017; Harkell, 2018).

Food products safety can benefit greatly from the application of predictive models for the evaluation of exposure and bioaccumulation to trace metals and the identification of risks based on aquatic ecosystem health condition.

The prediction of metal transfer along aquatic food webs depends significantly on understanding how organisms accumulate metals from their environment. It is important to recognise that aquatic organisms are exposed to trace metals from both soluble and dietary source which need to be factored in (Thomann et al., 1995; Diepens et al., 2015. Biokinetic models can provide critical information for our understanding of the key processes controlling metal bioaccumulation, thus explaining vast differences in metal body burdens found among different animal species (Luoma and Presser, 2000). Additionally, mechanistic models permit to incorporate variability in biokinetic parameters, thus allowing to find likely explanation of the different patterns of bioaccumulation seen in different species under various environmental conditions. Despite the number of existing food web bioaccumulation models (e.g., ECOFATE (Gobas et al., 1998), AQUAWEB v1.1 (Arnot and Gobas, 2004), BASS v 2.2 (Barber, 2008)), they are mostly designed for modelling exposures to nonpolar organic contaminants offering little support for addressing spatial and temporal variabilities in estimating exposures. On the other hand, the MERLIN-Expo exposure modelling tool (Ciffroy et al., 2016) was developed for a broad range of environmental pollutants including trace metals (Tanaka et al., 2011), allowing the user to adapt the model to specific requirements of localised exposure scenario (Fierens et al., 2016). For these reasons, it was selected as the main application in this study.

The main objective of the present study was to model concentration of trace metals in aquatic species occurring in Liaodong bay (Bohai Sea, China). The modelling exercise consisted of the calculation of metal concentration levels specific to invertebrate and fish organisms from measured water/sediment metal contamination data, and the comparison of model results with measured metal concentrations in aquatic species from Liaodong bay food web. Additionally, the application of sensitivity analysis aided in identifying the most critical parameters from the model that ultimately influenced the overall metal concentrations in organisms.

\section{Materials and methods}

\subsection{Description of study area and monitoring campaign}

The Daliao River estuary is located in southern Liaoning Province, NE China $\left(121^{\circ} 33^{\prime}-122^{\circ} 36^{\prime} \mathrm{E}, 40^{\circ} 26^{\prime}-41^{\circ} 27^{\prime} \mathrm{N}\right)$ (Fig. 1) and has representative characteristics of many estuaries in China with high pollution pressure. The Daliao River flows through many important largeor medium-sized industrial cities, combining with the Hun River and the Taizi River, and ultimately flows into the Liaodong Bay, Bohai Sea. 
The Daliao River watershed includes some of the traditional industrial hot spots of China and has been long affected by heavy industries, including chemical/petrochemical, steel-iron and machinery. It was reported that the Daliao River received about $60 \%$ of the pollutant discharge load of the entire Liao River watershed (Men et al., 2014). A large amount of pollutants ends up in the Daliao River and is transported into the estuary. Therefore, the aquatic environment quality of the estuary is greatly influenced by anthropogenic activities. In addition, it is well known that Liaodong Bay is one of the major fishing grounds in China, especially in the Daliao River estuary and its surrounding area. Therefore, seafood is locally highly consumed by the population and most of this seafood comes from the local fishing areas.

The monitoring campaigns were conducted in August 2014. The sampling sites were evenly distributed throughout the lower stretch of the Daliao River and the Daliao estuary region of Liaodong Bay. Water, surface sediment $(0-20 \mathrm{~cm})$ and biota samples were collected. Fishes and invertebrates were collected for the study by local commercial fishermen using trawl nets. All water samples were acidified with diluted nitric acid to a $\mathrm{pH}$ of $\leq 2.5$ at sampling sites. After the transport to the laboratory, the water samples were filtrated through $0.45 \mu \mathrm{m}$ glass fiber filters, and then analysed directly by ICP-MS (iCAP-Qc, Thermo Fisher). All sediment samples were freeze-dried and were ground through a 100-mesh $(150 \mu \mathrm{m})$ nylon sieve, and then were digested with $\mathrm{HNO}_{3}-\mathrm{HF}-\mathrm{HClO}_{4}$ to determine total concentration of metals using ICPMS (iCAP-Qc, Thermo Fisher). In addition, the physiological indexes (body weight, fish length, lipid fraction and moisture content) of the biota samples were measured before dissection. About $100 \mathrm{~g}$ of muscle (edible part) were taken from some individuals of each species and freeze-dried. Various organs where the concentration of metals where measured are given in Table 1 . The water content of the muscle tissues was determined gravimetrically by the difference in weights before and after freeze-drying. The dried muscle samples were ground into a fine powder using an agate mortar and pestle. Portions of the muscle samples was digested in a microwave oven using $\mathrm{HNO}_{3}-\mathrm{H}_{2} \mathrm{O}$ for $\mathrm{Cd}, \mathrm{Cr}, \mathrm{Cu}$, $\mathrm{Ni}, \mathrm{Pb}, \mathrm{Sb}$, and $\mathrm{Zn}$ (for determination by high resolution-inductively coupled plasma-mass spectrometry (HR-ICP-MS)), $\mathrm{HNO}_{3}-\mathrm{HClO}_{4}$ for As (for determination by hydride generation atomic fluorescence spectrometry (HG-AFS)), and 1:1 aqua regia for Hg (for determination by HGAFS).
Data used as model inputs constitute a subset of the data presented by Guo et al. (2016) and pertain to the area of Daliao River's mouth (five sampling sites numbered $1,2,3,4,5$ ). Input concentration of metals measured in sediments and water were averaged over all five sampling sites located at the Daliao river's mouth. Nine metals (As, Cd, $\mathrm{Cu}, \mathrm{Ni}, \mathrm{Pb}, \mathrm{Zn}, \mathrm{Sb}, \mathrm{Hg}, \mathrm{Cr}$ ) were measured in various organs of selected aquatic species (Table 1). Only those measured in muscles were compared with bioaccumulation simulation results.

\subsection{Structure of the aquatic food web}

To better understand the bioaccumulation processes influencing the chemicals concentration in aquatic organisms, a site-specific food web for the study area is needed. A food web in Liaodong Bay was proposed by Wan et al. $(2007,2008)$. This food web has been slightly adapted for the application and includes, besides phytoplankton and zooplankton compartments, six species among which three invertebrates (Shortnecked clam (Ruditapes philippinarum), Veined rapa whelk (Rapana venosa peichiliensis), Swimming crab (Portunus trituberculatus), and three fish species Mullet (Liza haematocheila), Wolffish (Odontamblyopus rubicundus), Weever (Lateolabrax japonicus)), constituting a simplified food web of Liaodong Bay (Fig. 2). The selected species in this study cover specific trophic roles from primary producers to top predators. In addition, these species are also relevant in the diet of local population and it is worth including them in the assessment of human exposure to environmental contaminants.

\subsection{Model description}

MERLIN-Expo is a library of models that was developed in the frame of the FP7 EU project 4FUN in order to provide an integrated assessment tool for state-of-the-art exposure assessment for environment, biota and humans, allowing the detection of scientific uncertainties at each step of the exposure process (Ciffroy et al., 2016). The aquatic bioaccumulation model implemented in MERLIN-Expo accounts separately for bioaccumulation from the dissolved phase and from food (Giubilato et al., 2016) permitting delineation and quantitative evaluation of the two sources. The biokinetic bioaccumulation model can be used to describe the time-course of the internal concentration

Table 1

Measured metal concentrations in various organs of selected aquatic species.

\begin{tabular}{|c|c|c|c|c|c|c|c|c|c|c|}
\hline \multirow[t]{2}{*}{ Organism } & \multirow[t]{2}{*}{ Organ } & As & $\mathrm{Cd}$ & $\mathrm{Cr}$ & $\mathrm{Cu}$ & $\mathrm{Hg}$ & $\mathrm{Ni}$ & $\mathrm{Pb}$ & $\mathrm{Sb}$ & $\mathrm{Zn}$ \\
\hline & & \multicolumn{9}{|c|}{$\mathrm{mg} / \mathrm{kg} \mathrm{dw}$} \\
\hline Clam & Muscle & 6.08 & 1.2 & 6.18 & 9.3 & 0.03 & 14.88 & 1.13 & 0.06 & 106 \\
\hline Whelk & Muscle & 5.32 & 0.5 & 13.53 & 29.6 & 0.07 & 0.8 & 0.21 & 0.03 & 59 \\
\hline Crab & Muscle & 6.88 & 1.6 & 0.28 & 65.3 & 0.11 & 1.14 & 0.51 & 0.09 & 148 \\
\hline MEAN $_{\text {invert }}$ & & 6.1 & 1.0 & 6.7 & 34.7 & 0.07 & 5.6 & 0.6 & 0.1 & 104.3 \\
\hline $\mathrm{SD}_{\text {invertebrat }}$ & & 0.8 & 0.5 & 6.6 & 28.4 & 0.04 & 8.0 & 0.5 & 0.03 & 44.5 \\
\hline \multirow[t]{7}{*}{ Mullet } & Muscle & 3.66 & 0.01 & 0.5 & 0.7 & 0.02 & 0.15 & 0.23 & 0.06 & 19 \\
\hline & Fish gill & 7.1 & 0.1 & 4.22 & 7.8 & 0.03 & 0.69 & 1.05 & 0.03 & 89 \\
\hline & Fishskin & 2.58 & 0.02 & 11.61 & 2.6 & 0.02 & 0.56 & 1.1 & 0.04 & 77 \\
\hline & Fish liver & 7.48 & 0.7 & 0.4 & 43.5 & 1.82 & 0.86 & 0.71 & 0.06 & 158 \\
\hline & Fish intestine & 7.03 & 1.1 & 3.25 & 48.8 & 0.08 & 3.31 & 1.71 & 0.06 & 155 \\
\hline & Fish stomach & 4.03 & 0.2 & 4.31 & 15.4 & 0.06 & 1.27 & 0.43 & 0.03 & 130 \\
\hline & Fish heart & 4.4 & 0.4 & 0.15 & 33.4 & 0.08 & 0.33 & 0.14 & 0.02 & 96 \\
\hline \multirow[t]{3}{*}{ Wolffish } & Fish gill & na & 0.2 & 2.35 & 6.8 & na & 1.19 & 1.41 & 0.03 & 106 \\
\hline & Fishskin & 1.09 & 0.1 & 10.46 & 3.5 & 0.03 & 0.88 & 0.19 & 0.03 & 100 \\
\hline & Fish intestine & 2.91 & 0.3 & 0.22 & 4.7 & 0.08 & 0.3 & 0.12 & 0.02 & 39 \\
\hline \multirow[t]{6}{*}{ Weever } & Muscle & 3.66 & 0.02 & 0.21 & 1 & 0.09 & 0.16 & 0.88 & 0.13 & 30 \\
\hline & Fish gill & 3.37 & 0.1 & 3.98 & 3.5 & 0.02 & 2.29 & 0.89 & 0.03 & 112 \\
\hline & Fishskin & 1.9 & 0.02 & 18.61 & 4.2 & 0.04 & 0.53 & 0.19 & 0.02 & 93 \\
\hline & Fish liver & 6.73 & 0.2 & 0.18 & 27.7 & 0.04 & 0.2 & 0.08 & 0.01 & 173 \\
\hline & Fish intestine & 8.18 & 0.2 & 2.71 & 7 & 0.02 & 0.26 & 0.1 & 0.02 & 52 \\
\hline & Fish stomach & 4.28 & 0.5 & 0.61 & 19.7 & 0.03 & 0.38 & 0.17 & 0.03 & 103 \\
\hline \multicolumn{2}{|c|}{ MEAN $_{\text {fish }}$ (all organs) } & 4.6 & 0.3 & 4.0 & 14.4 & 0.2 & 0.8 & 0.6 & 0.04 & 95.8 \\
\hline \multicolumn{2}{|c|}{$\mathrm{SD}_{\text {fish }}$ (all organs) } & 2.4 & 0.3 & 5.2 & 15.7 & 0.4 & 0.9 & 0.5 & 0.03 & 45.3 \\
\hline
\end{tabular}




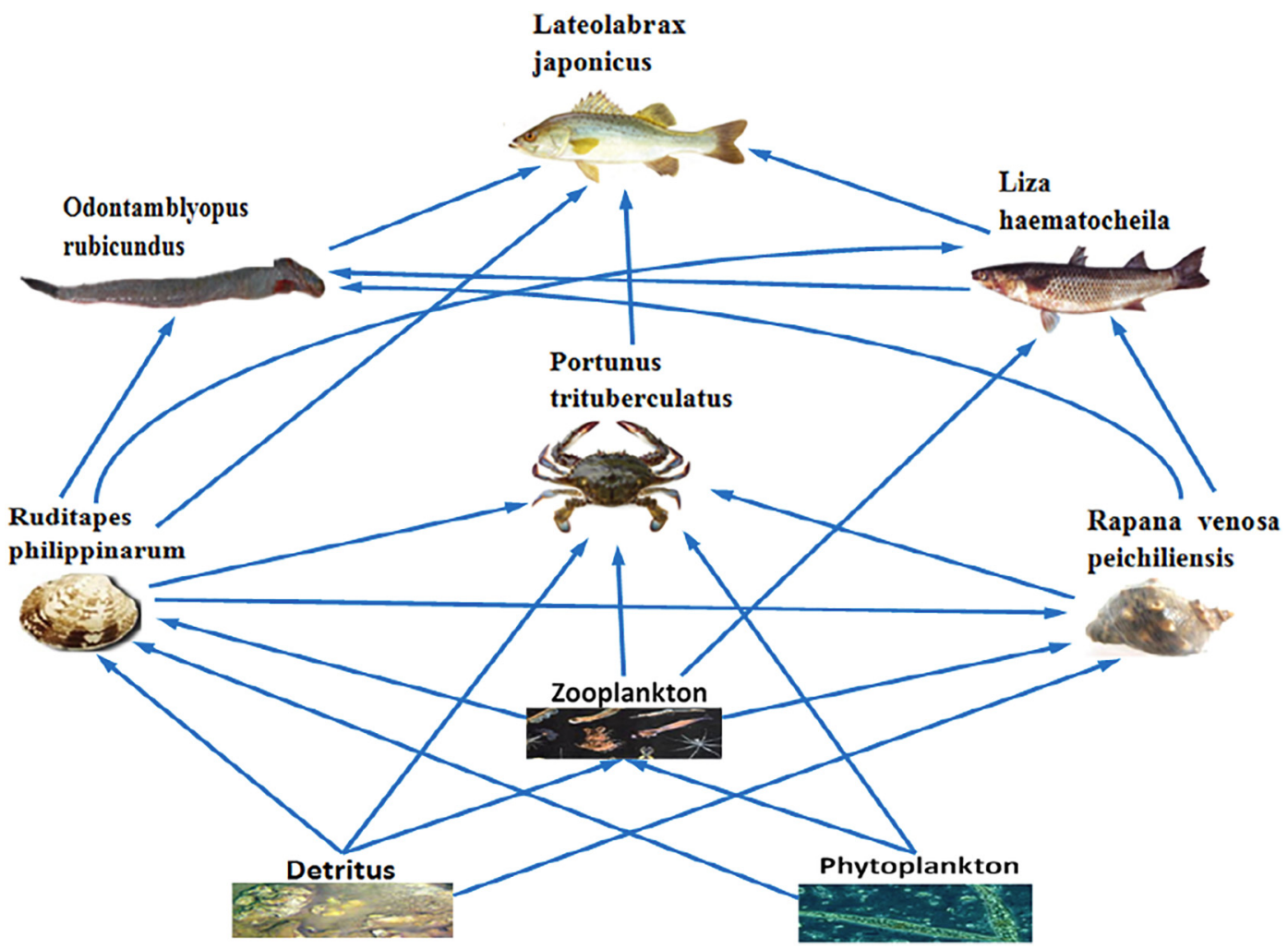

Fig. 2. Aquatic food web for Liaodong Bay.

Adapted from Wan et al. (2007, 2008).

dynamics. In a simple biokinetic model the metal concentration in an organism is controlled by the balance between uptake and elimination and all the processes that potentially lead to metal bioaccumulation are investigated quantitatively. In this model, metals are accumulated by animals through uptake from both dissolved and dietary phases, and the uptake from both routes are considered additive (Fig. 3). Input data required by the model include parameters, which are constant over each simulation and can be classified as chemical related parameters (e.g., physico-chemical properties of target chemicals) and biota related parameters (e.g., diet preferences, physiological parameters of selected species), and environmental data (e.g., concentrations in environmental media such as water or sediment, water temperature).

Phytoplankton, Invertebrate and Fish models require the same chemical-related parameters; moreover, Phytoplankton model requires as input also the water-organic carbon partition coefficient. Input values for biological parameters for the species have been derived from available literature and free databases. Diet preferences for the organisms have been defined according to available literature data and adapting the diet matrix proposed by (Webster and Ellis, 2012).

The bioaccumulation of chemicals in aquatic organisms is based on the "Optimal Modelling for EcotoxicoloGical Applications" (OMEGA) modelling approach proposed by Hendriks and colleagues (Hendriks et al., 2001; Hendriks and Heikens, 2001; Hendriks, 2007).

The detailed description of processes can be found in Radomyski et al. (2018).

Uptake of metals $\left(\mathrm{L} \mathrm{kg}_{\mathrm{fw}}{ }^{-1} \mathrm{~d}^{-1}\right)$ via the respiratory pathway is given by Eq. (1):

$k_{\text {uptake }_{\text {resp }}}=B C F_{\text {metal }} \cdot 0.002 \cdot W^{-\kappa}$

where $\mathrm{BCF}_{\text {metal }},\left(\mathrm{L} \mathrm{kg}_{\mathrm{fw}}{ }^{-1}\right)$, bioconcentration factor for metal, $\mathrm{W}$ animal weight $(\mathrm{kg})$ and $\mathrm{\kappa}(-)$ allometric constant.

Further, $\mathrm{BCF}_{\text {metal }}$ is given by Eq. (2):

$\ln (B C F)=a_{B C F}+b_{B C F} \cdot \ln \left(C_{\text {water }}\right)$
However, this relationship was parameterized for some metals only (antimony, chromium and mercury were not included).

Dietary uptake $\left(\mathrm{kg}_{\mathrm{fw}} \mathrm{kg}_{\mathrm{fw}}{ }^{-1} \mathrm{~d}^{-1}\right)$ is calculated using the following formula (Eq. (3)):

$k_{\text {ingestion }}=\left(\right.$ Assimilated $_{\text {food }} / 1-$ Assimilated $\left._{f \circ o d}\right) \cdot 0.002 \cdot W^{-\kappa}$

where Assimilated food $_{\text {, }}(-)$, fraction of assimilated food.

Finally, the elimination of metals consists of two depuration processes, i.e. excretion $\left(\mathrm{d}^{-1}\right)$ and egestion $\left(\mathrm{d}^{-1}\right)$, described in Eqs. (4) and (5) respectively.

$k_{\text {egestion }}=\left(1-\right.$ Assimilated $\left._{\text {food }}\right) \cdot k_{\text {ingestion }_{\text {Assimilated }}}$ Aood $_{\text {Ass }}$

$k_{\text {excretion }}=k_{\text {uptake }} / B C F_{\text {metal }}$

\subsection{Model parameterisation and simulation settings}

All input parameter values including uncertainties are included in Supplementary Information file (Tables S1-S3). There are four groups of parameters: general physiological (allometric exponent, fraction of assimilated food), specific physiological (weight, length), chemical specific (slope and intercept of $\mathrm{BCF}_{\text {metal }}$ water concentration relationship) and environmental parameters (metal concentration in sediments/water).

Due to the specific model parameterisation and the application domain of the MERLIN-Expo bioaccumulation model, it is feasible to simulate internal concentration in invertebrates and fishes to six metals, namely $\mathrm{As}, \mathrm{Cd}, \mathrm{Cu}, \mathrm{Ni}, \mathrm{Pb}$, and $\mathrm{Zn}$. Simulation results were expressed on dry weight whole body basis and then compared with observed concentrations (dry weight) in edible parts of animal such as muscles.

Metal concentrations in exposure media (water and sediments) were used as input to the bioaccumulation model for fish and invertebrates. 


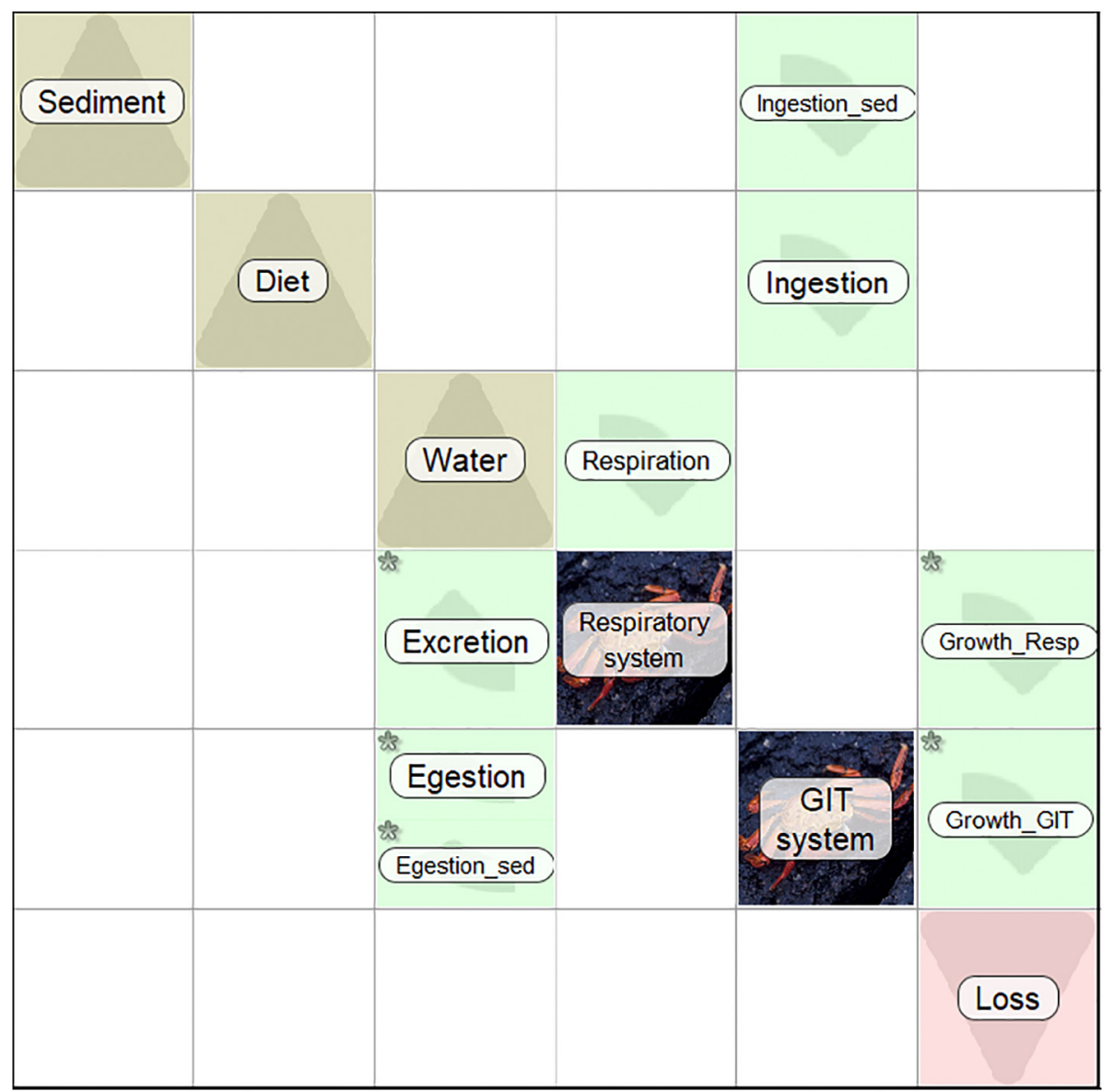

Fig. 3. Schematic representation of compartments, processes, sources and sinks involved in accumulation in MERLIN-Expo bioaccumulation model (GIT: Gastro Intestinal Tract).

\subsection{Sensitivity analysis}

Variability in input parameters reduces the certainty of model predictions, therefore emphasizing sensitivity analysis (SA) of the model is important in order to ensure that the model is robust within the full range of variation in input parameters. The analysis of the most influential parameters was focused on those included in the bioaccumulation model. SA was applied to the bioaccumulation models (internal exposure to metals in aquatic organisms) employing the Morris and EFAST methods (Radomyski et al., 2016).

Firstly, input parameters to the bioaccumulation models were screened by the Morris method (Morris, 1991). It is based on a onefactor-at-a-time screening design, providing qualitative ranking of the influence of the input parameters on the model outputs. The non-influential model parameters are characterised by low values for $\mu^{*}$ and $\sigma$. Influential input parameters, on the other hand, can have linear effects and no interaction, i.e., for which $\mu^{*}$ is high and $\sigma$ is low, or nonlinear effects and/or interactions, i.e. for which $\sigma$ is high regardless of the value of $\mu^{*}$.

Secondly, EFAST method was performed in order to seek main contributors to the variability in internal concentration of metals in selected aquatic species. EFAST method (Saltelli et al., 1999) is a variance-based sensitivity analysis technique that calculates total order sensitivity index taking into account all interactions between parameters.

This two-step approach allowed also to compare a method that takes into account interactions between parameters with one that does not.

\section{Results and discussion}

\subsection{Metals in water column and sediment}

Measured concentrations of examined trace metals in sediments and in water are reported in Table S4. Eight metals show higher concentration in sediments than in water, the highest difference was detected for $\mathrm{Pb}$ and $\mathrm{Cr}$. Only $\mathrm{Zn}$ shows inverse sediment-water relationship. Concentrations of metals in sediments were compared with recent literature concentration data collected for the Liadong Bay and the Bohai Bay (Table S5). Although sediment concentration values are characterised by significant variability, according to ranges of concentration and standard deviation, there is a consistency in the order of magnitude between results obtained in the present work and values collected from other studies in Liaodong Bay and Bohai Bay (Xu et al., 2009; Pan and Wang, 2012). The largest deviation is observed for $\mathrm{Hg}$, with values of $0.037 \pm 0.098 \mathrm{mg} / \mathrm{kg} \mathrm{dw}$ in this study and a mean value equal to 0.57 (in the range $0.25-0.97$ ) $\mathrm{mg} / \mathrm{kg} \mathrm{dw}$ reported by Pan and Wang (2012).

Concentration thresholds used as sediment quality guidelines at the international level were collected and reported in Table S5. In few instances the concentration of metals measured in sediments exceeds selected international thresholds: these are As (> NOAA ERL and Canadian SQG), Cr (> Canadian SQG), and Ni (> NOAA ERL). No metal exceeds the Chinese sediment quality guideline.

\subsection{Observed and predicted metals in aquatic biota}

MERLIN-Expo modules were run and modelled results for ecological 
targets (metal concentration in aquatic organisms) were then compared with monitoring data. Specifically, yielded whole-body metal concentrations by the bioaccumulation models were compared with metals detected in muscles of selected species (apart from wolffish). The results are also discussed referring to other internal organs where metals were detected (Table 1).

Interestingly, simulation shows a general trend regardless the considered metal and its concentration in exposure media, showing systematically the highest estimated whole-body concentration for whelk and the lowest estimated concentration for mullet and weever for all metals. Observed metal concentrations in invertebrates and fish varied widely among taxa and even within closely related taxa (Table 1). Possible explanations for the variability in metal concentrations include species-specific differences in bioaccumulation dynamics as well as differences in metal exposures due to habitat characteristics (e.g., temperature) influencing metal speciation and partitioning, or to dietary preferences, foraging behaviours, food web structure, and trophic position (Reinfelder et al., 1998; Croteau et al., 2002).

Selected invertebrate benthic species tend to accumulate metals in higher concentrations $(\mathrm{mg} / \mathrm{kg} \mathrm{dw})$ than fishes as shown by the simulated and observed results: As (invertebrates $6.1 \pm 0.8$, fishes $4.6 \pm 2.4$ ), Cd (invertebrates $1.0 \pm 0.5$, fishes $0.3 \pm 0.3$ ), $\mathrm{Cr}$ (invertebrates $6.7 \pm 6.6$, fishes $4.0 \pm 5.2$ ), $\mathrm{Cu}$ (invertebrates $34.7 \pm 28.4$, fishes $14.4 \pm 15.7$ ), $\mathrm{Hg}$ (invertebrates $0.07 \pm 0.04$, fishes $0.2 \pm 0.4$ ), $\mathrm{Ni}$ (invertebrates $5.6 \pm 8.0$, fishes $0.8 \pm 0.9$ ), $\mathrm{Pb}$ (invertebrates $0.62 \pm 0.47$, fishes $0.59 \pm 0.53$ ), Sb (invertebrates $0.1 \pm 0.03$, fishes $0.04 \pm 0.03$ ), Zn (invertebrates $104.3 \pm 44.5$, fishes $95.8 \pm 45.3$ ).

Fish organs where As accumulates in larger amounts are fish intestine and liver $(6.5 \pm 2.1)$ (Table 1$)$. Both experimental and simulation results confirm previous observations that As internal concentrations decrease with the increase of trophic level in both marineand freshwater food chains (Azizur Rahman et al., 2012). GB 27622017 refers to both total and inorganic arsenic in food stuff, the limits however are only prescribed for inorganic arsenic in an aquatic animal and its products (excluding fish and fish products) (with a limit of $0.5 \mathrm{mg} / \mathrm{kg}$ ), and fish and fish products (with a limit of $0.1 \mathrm{mg} / \mathrm{kg}$ ).

The comparison of measured and observed values demonstrates that the model overestimates the accumulated level of $\mathrm{Cd}$ of around 1-fold in mullet and weever (Fig. 4). Experimental data show an increase in internal concentration with trophic position for invertebrates, however not progressive. Indeed several studies point at possible biomagnification of Cd concentration in aquatic food webs (Croteau et al., 2005; Mathews and Fisher, 2008). Another study where bioaccumulation of 27 metals in the freshwater amphipod Hyalella Azteca was tested suggests that in the case of $\mathrm{Cd}$ the contribution from food had a significant effect on its overall metal body concentration (Borgmann et al., 2007). $\mathrm{Cd}$ measured in crab $(1.6 \mathrm{mg} / \mathrm{kg} \mathrm{dw})$ was shown to exceed Chinese regulatory maximum value for crustaceans set to $0.5 \mathrm{mg} / \mathrm{kg}$. There is however no violation of the $\mathrm{Cd}$ maximum limit concentration $(0.1 \mathrm{mg}$ / $\mathrm{kg}$ ) laid down for fish, if concentration in muscles were only considered ( $0.01 \mathrm{mg} / \mathrm{kg} \mathrm{dw}$ and $0.02 \mathrm{mg} / \mathrm{kg} \mathrm{dw}$ in mullet and weever respectively) (GB 2762-2017).

The field observation of $\mathrm{Cu}$ accumulation is characterised by a systematic increase in concentration in the following order: clam $(9.3 \mathrm{mg} / \mathrm{kg} \mathrm{dw})<$ whelk $(29.6 \mathrm{mg} / \mathrm{kg} \mathrm{dw})<\operatorname{crab}(47.9 \mathrm{mg} / \mathrm{kg} \mathrm{dw})$. $\mathrm{Cu}$ is a nutritionally relevant element, thus animals can regulate its accumulation. One way of active regulation of internal $\mathrm{Cu}$ concentration is by sequestering it into the liver, which is followed by elimination via the bile. Effects of this mechanism can be seen in fishes, where high concentration of $\mathrm{Cu}$ was detected in liver of mullet $(48.8 \mathrm{mg} / \mathrm{kg} \mathrm{dw})$ and weever $(27.7 \mathrm{mg} / \mathrm{kg} \mathrm{dw})$.

Clam has the highest Ni concentration in muscles among all studied animals and tissues $(14.88 \mathrm{mg} / \mathrm{kg} \mathrm{dw})$. Apart from clam, data suggest that Ni evenly accumulates in all species regardless trophic level. This is contrary to the model predictions which show an inverse internal concentration-trophic level relationship (Fig. 4). Moreover, enough evidence is lacking to demonstrate that Ni biomagnifies in food webs (Deforest et al., 2007).

Likewise, $\mathrm{Pb}$ accumulates evenly in the selected species in this study. Organ specific measurements show that $\mathrm{Pb}$ does not accumulate significantly in any of the analysed body parts. Simulations yielded highly overestimated $\mathrm{Pb}$ internal concentration compering to the observed ones and the most pronounced difference is shown for whelk (Fig. 4). There is no proof that $\mathrm{Pb}$ tissue concentration can be actively regulated by aquatic biota nor that it accumulates in higher trophic levels of aquatic food webs (Chen and Folt, 2000). Mean measured Pb concentrations in crustaceans and fish are compliant with the $\mathrm{Pb}$ maximum values concentration in fish and crustaceans $(0.5 \mathrm{mg} / \mathrm{kg})$ and in bivalves $(1.5 \mathrm{mg} / \mathrm{kg})$ prescribed in the Chinese National Food Safety Standard (GB 2762-2017).

The highest $\mathrm{Zn}$ concentration was measured in crab muscles (148 mg/kg dw), whereas among fishes $\mathrm{Zn}$ was detected predominantly in mullet liver ( $158 \mathrm{mg} / \mathrm{kg} \mathrm{dw})$, intestine $(155 \mathrm{mg} / \mathrm{kg} \mathrm{dw})$, and stomach $(130 \mathrm{mg} / \mathrm{kg} \mathrm{dw})$, and in weever $\mathrm{Zn}$ reached $173 \mathrm{mg} / \mathrm{kg}$ in liver. Wolffish accumulated $\mathrm{Zn}$ mostly in intestine $(139 \mathrm{mg} / \mathrm{kg} \mathrm{dw})$. The overall model simulation results is in good agreement with the observed internal concentrations i.e. the estimates are indeed within the same order of magnitude (Fig. 4). McGeer et al., 2003 demonstrated on a large pool of data on aquatic biota that there is no relationship between exposure concentration and whole-body concentration of $\mathrm{Zn}$, even at concentration levels bound to cause chronic effects. When $\mathrm{Zn}$ exposure levels are chronically elevated, aquatic animals are able to control bioaccumulation by actively regulating their body $\mathrm{Zn}$ concentrations. There is little evidence of $\mathrm{Zn}$ biomagnification in aquatic food webs (McGeer et al., 2003).

$\mathrm{Hg}$ average measured concentration in muscles of selected invertebrates attained $0.07 \pm 0.04(\mathrm{mg} / \mathrm{kg} \mathrm{dw})$ and in fish species $0.055 \pm 0.05(\mathrm{mg} / \mathrm{kg} \mathrm{dw}) . \mathrm{Hg}$ accumulated distinctively higher in Mullet's liver reaching $1.82(\mathrm{mg} / \mathrm{kg} \mathrm{dw})$ comparing to other body parts in studied species (Table 1). Although it is generally agreed that methylmercury is the most bioaccumulative form of $\mathrm{Hg}$ and it is known to biomagnify in aquatic food webs (Chen et al., 2014) we did not clearly observe this phenomenon in our dataset, likely owing to its scarcity. Additionally it would be of interest to test dependency of $\mathrm{Hg}$ internal concentration in various tissues on varying external exposure (Williams et al., 2010; Chen et al., 2016).

Measured data indicate that chromium accumulates in muscles at higher levels in invertebrates than in fishes, that is $6.66 \pm 6.65$ and $0.36 \pm 0.21(\mathrm{mg} / \mathrm{kg} \mathrm{dw})$ respectively. Among invertebrates the highest concentration reached 6.18 and $13.53(\mathrm{mg} / \mathrm{kg} \mathrm{dw})$ in muscles of clam and whelk respectively. Measured levels of $\mathrm{Cr}$ were reported to be unambiguously highest in fish skin for all three species, 12.45 (Mullet), 10.46 (Wolffish) and $18.61(\mathrm{mg} / \mathrm{kg} \mathrm{dw}$ ) (Weever). There is no evidence of increasing $\mathrm{Cr}$ concentration with trophic level.

$\mathrm{Sb}$ muscle concentration does not differ among considered aquatic species, both invertebrates and fishes. Only weever shows slightly increased Sb level in muscles $(0.13 \mathrm{mg} / \mathrm{kg} \mathrm{dw})$.

In general, metal BCF is not an intrinsic property of metals nor organisms. Moreover, application of metal BCF to hazard identification may erroneously suggest that hazard is less significant at elevated exposure concentrations. The often observed inverse metal tissue concentration - BCF value relationship arises from controlled metal uptake mechanism. The absorption of metals from food is highly variable because of the variety of free and bound forms of the ions that are possible in food. However, modelling has shown that many metals are found to be accumulated significantly from diet in diverse invertebrates (Baumann and Fisher, 2011). In fact, also for some fish species, while having very low gill uptake of waterborne metals, their dietary uptake becomes the predominant pathway for metal accumulation (Wang, 2011). Among many biological and physico-chemical factors affecting accumulation of metals in aquatic trophic webs, the competition of 

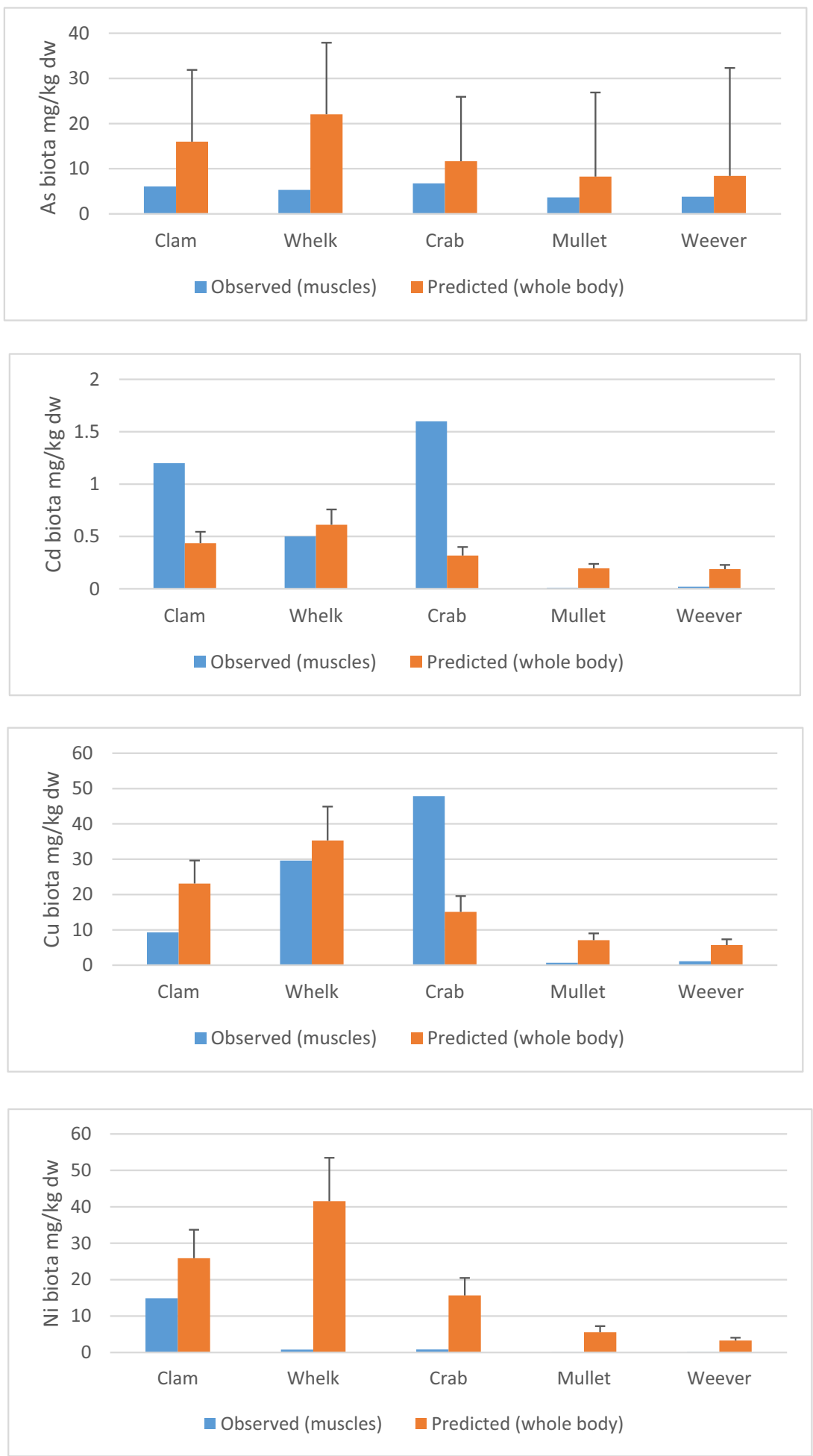

Fig. 4. Observed and predicted (mean and 95th\%) metal concentration in aquatic species.

related metal ions for active transport sites adds variability to the metal absorption (Veltman et al., 2009).

Another study by Guo et al. (2016) carried out in Daliao River estuary on a larger dataset demonstrated large variability in accumulated metals measured in muscles of sixteen benthic invertebrates and nine fish species (Table 2).

\subsection{Sensitivity analysis}

Figs. S1-S6 present the results of the application of Morris method. The charts show that an intercept of BCF-exposure concentration relationship for metals (a_BCF) is identified as the single most influential parameter, which in itself is positively correlated to the slope of BCFexposure concentration relationship for metals (b_BCF) (also characterised by higher $\sigma$ and $\mu^{*}$ values). The third parameter of interest is a slope in fish weight-length relationship. 


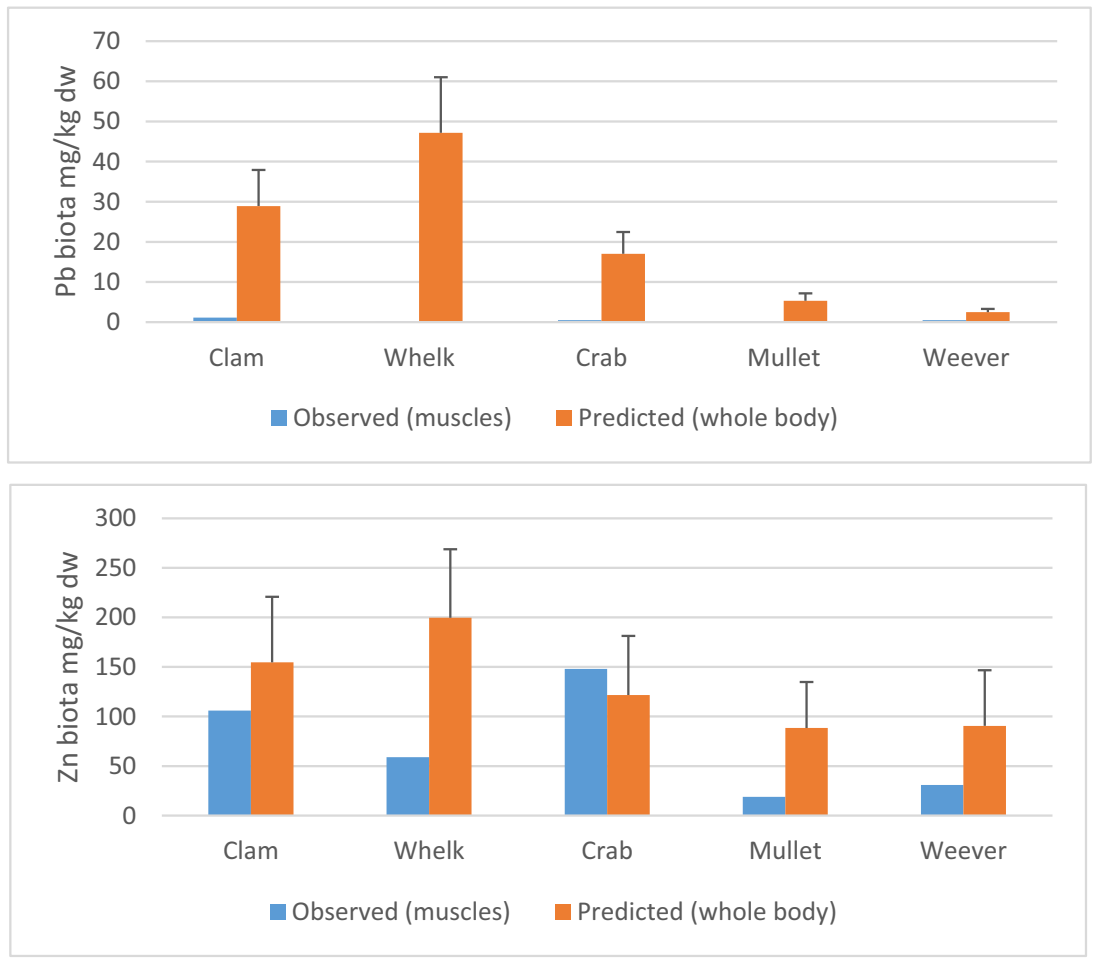

Fig. 4. (continued)

Table 2

Metals concentration ranges (min-max) observed in muscles of 5 species and predicted whole-body concentration in this study compared with results obtained by Guo et al., 2016 in the same study area of Daliao River estuary for 25 aquatic species.

\begin{tabular}{lccc}
\hline Metal & $\begin{array}{l}\text { Observed min-max } \\
\text { conc. (this study) } \\
\mathrm{mg} / \mathrm{kg} \mathrm{dw}\end{array}$ & $\begin{array}{l}\text { Predicted min-max } \\
\text { conc. (this study) } \\
\mathrm{mg} / \mathrm{kg} \mathrm{dw}\end{array}$ & $\begin{array}{l}\text { Observed min-max } \\
\text { conc. } \\
\text { (Guo et al., 2016) } \\
\mathrm{mg} / \mathrm{kg} \mathrm{dw}\end{array}$ \\
\hline $\mathrm{As}$ & $3.7-6.1$ & $8.3-22.1$ & $1-18$ \\
$\mathrm{Cd}$ & $0.01-1.60$ & $0.2-0.6$ & $0.01-9.30$ \\
$\mathrm{Cr}$ & $0.2-13.5$ & & $0.2-36.1$ \\
$\mathrm{Cu}$ & $0.7-47.9$ & $5.7-35.3$ & $0.7-145.4$ \\
$\mathrm{Hg}$ & $0.02-0.11$ & & $0.01-1.00$ \\
$\mathrm{Ni}$ & $0.15-14.88$ & $3.3-41.5$ & $0.1-14.9$ \\
$\mathrm{~Pb}$ & $0.2-1.1$ & $2.5-47.2$ & $0.1-2.5$ \\
$\mathrm{Sb}$ & $0.03-0.13$ & & $0.02-0.14$ \\
$\mathrm{Zn}$ & $19-148$ & $88.4-199.7$ & $19.3-221.1$
\end{tabular}

Figs. S7-S12 show the results of EFAST method for single species. In the top ten ranked parameters with the highest total sensitivity index (TSI) yielded by the EFAST method, the most important ones are Assimilated_food, intercepts and slopes of BCF-exposure concentration relationship as well as those used in fish weight-length model (Fig. 5).

Both Morris method and EFAST are comparable with their high ranking of slopes and intercepts from BCF-exposure concentration and fish weight-length sub-models. Similar outcomes of the two approaches in classifying the importance of the ecological parameters were already noted by Ciric et al. (2012). EFAST additionally highlights the importance of the parameter Assimilated_food, which stands for assimilation efficiency of adsorbed food items from the dietary matrix. Assimilated_food is not pointed as influential by the Morris method because this method does not decompose variance of the model output and does not consider influences between parameters. On the other hand, EFAST accounts for influences with other parameters, thus Assimilated_food appears as the most influential one, which indeed drives how much of the contaminants are absorbed by the organism from its diet.

Among important physico-chemical parameters are log10_Kd_DOC and p_carbon_phytoplankton, both used to calculate exchanges of contaminants between phytoplankton and its surrounding environment. Metals can sorb to both living and non-living particles such as phytoplankton and suspended particulate matter, respectively. Sorption can come about through active or passive mechanism, and its pathway is dependent on metal of interest. In general, the metal partition coefficient $\mathrm{Kd}$, or sorption distribution coefficient, is the ratio of sorbed metal concentration to the dissolved metal concentration at equilibrium. Carbon fraction represents phytoplankton cell carbon pool, where accumulation of metals may take place. Carbon fraction is used in expressing excretion of the metals ( $\mathrm{k}_{-}$excretion_metals) from the planktonic cell.

\section{Conclusions}

Concerns over high metal concentrations in the aquatic environment stem primarily from the risk these contaminants can pose for living organisms, including, at the top of the food chain, people who might consume contaminated seafood.

We have demonstrated how the recently developed tool MERLINExpo can be used to simulate site specific exposure for aquatic organisms to several trace metals. The application of the model was tailored to the exposure scenario in Liaodong Bay using as inputs physiological data of the target aquatic organisms and real life environmental data collected from the fishing area of the lower stretch of the Daliao river.

We have obtained satisfactory modelled results especially for bioaccumulation of $\mathrm{Zn}$ and As, which show the best agreement with measured values in aquatic organisms. The sensitivity analysis complemented the modelling of bioaccumulation by allowing to identify crucial parameters for simulating the internal exposure of organism to metals. Food assimilation efficiencies of selected aquatic species seem to be the key components of the modelling, driving the variability of internal exposure to heavy metals.

The applied model can be improved by including factors such as environmental (e.g., metal speciation) and physiological processes 

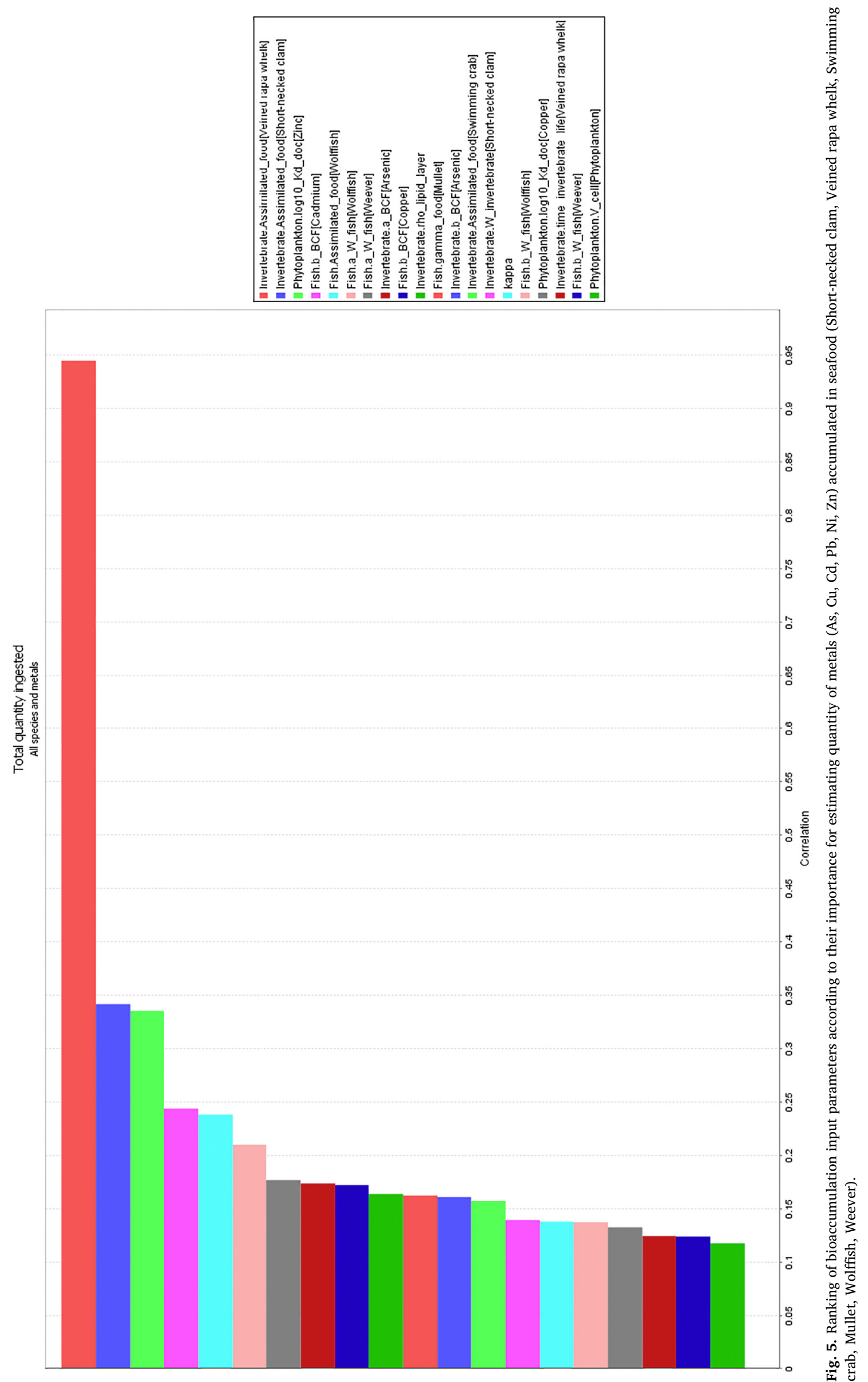
(homeostasis) involved in metal bioaccumulation, for a better description of the amount of trace metals taken up by target aquatic organisms in the perspective of both ecological and human health risk assessment. Another aspect where improvement of modelling can be sought is to distinguish between physiologically essential metal concentration, internally stored and detoxified, and excess of metal accumulation that could lead to adverse effects. Subsequently, the extension of bioaccumulation modelling to include specific metal water chemistry such as modelling metal speciation and focusing on physiological process responsible for homeostasis should be pursued.

The collection of additional monitoring data in the Liaodong Bay could support in the future the extension of the modelling exercise to estimate the exposure of local population to trace metals through the ingestion of contaminated fish and seafood.

\section{Acknowledgements}

This work was financially supported by the European Union Seventh Framework Programme (FP7/2007-2013) under grant agreement no. 269233-GLOCOM (Global Partners in Contaminated Land Management) and by the Chinese Ministry of Science and Technology (No. 2012CB525005).

\section{Appendix A. Supplementary data}

Supplementary data to this article can be found online at https:// doi.org/10.1016/j.marpolbul.2018.11.002.

\section{References}

Arnot, J.A., Gobas, F.A.P.C., 2004. A food web bioaccumulation model for organic chemicals in aquatic ecosystems. Environ. Toxicol. Chem. 23, 2343-2355. https://doi. org/10.1897/03-438.

Azizur Rahman, M., Hasegawa, H., Peter Lim, R., 2012. Bioaccumulation, biotransformation and trophic transfer of arsenic in the aquatic food chain. Environ. Res. 116, 118-135. https://doi.org/10.1016/j.envres.2012.03.014.

Barber, M.C., 2008. Dietary uptake models used for modeling the bioaccumulation of organic contaminants in fish. Environ. Toxicol. Chem. 27, 755. https://doi.org/10. 1897/07-462.1.

Baumann, Z., Fisher, N.S., 2011. Relating the sediment phase speciation of arsenic, cadmium, and chromium with their bioavailability for the deposit-feeding polychaete Nereis succinea. Environ. Toxicol. Chem. 30, 747-756. https://doi.org/10.1002/etc. 436.

Borgmann, U., Couillard, Y., Grapentine, L.C., 2007. Relative contribution of food and water to 27 metals and metalloids accumulated by caged Hyalella azteca in two rivers affected by metal mining. Environ. Pollut. 145, 753-765. https://doi.org/10.1016/j. envpol.2006.05.020.

Chen, C.Y., Folt, C.L., 2000. Bioaccumulation and diminution of arsenic and lead in a freshwater food web. Environ. Sci. Technol. 34, 3878-3884. https://doi.org/10. 1021/es991070c.

Chen, C.Y., Borsuk, M.E., Bugge, D.M., Hollweg, T., Balcom, P.H., Ward, D.M., Williams, J., Mason, R.P., 2014. Benthic and pelagic pathways of methylmercury bioaccumulation in estuarine food webs of the Northeast United States. PLoS One 9, e89305. https://doi.org/10.1371/journal.pone.0089305.

Chen, C., Ward, D., Williams, J., Fisher, N., 2016. Metal bioaccumulation by estuarine food webs in New England, USA. J. Mar. Sci. Eng. 4, 41. https://doi.org/10.3390/ jmse4020041.

Ciffroy, P., Alfonso, B., Altenpohl, A., Banjac, Z., Bierkens, J., Brochot, C., Critto, A., De Wilde, T., Fait, G., Fierens, T., Garratt, J., Giubilato, E., Grange, E., Johansson, E., Radomyski, A., Reschwann, K., Suciu, N., Tanaka, T., Tediosi, A., Van Holderbeke, M., Verdonck, F., 2016. Modelling the exposure to chemicals for risk assessment: a comprehensive library of multimedia and PBPK models for integration, prediction, uncertainty and sensitivity analysis - the MERLIN-Expo tool. Sci. Total Environ. 568, 770-784. https://doi.org/10.1016/j.scitotenv.2016.03.191.

Ciric, C., Ciffroy, P., Charles, S., 2012. Use of sensitivity analysis to identify influential and non-influential parameters within an aquatic ecosystem model. Ecol. Model. 246, 119-130. https://doi.org/10.1016/j.ecolmodel.2012.06.024.

Commission Regulation (EC) No., 1881/2006. Setting maximum levels for certain contaminants in foodstuffs. (20 December 2006).

Croteau, M.-N., Hare, L., Tessier, A., 2002. Influence of temperature on Cd accumulation by species of the biomonitor Chaoborus. Limnol. Oceanogr. 47, 505-514.

Croteau, M.-N., Luoma, S.N., Stewart, A.R., 2005. Trophic transfer of metals along freshwater food webs: evidence of cadmium biomagnification in nature. Limnol. Oceanogr. 50, 1511-1519.

Deforest, D.K., Brix, K.V., Adams, W.J., 2007. Assessing metal bioaccumulation in aquatic environments: the inverse relationship between bioaccumulation factors, trophic transfer factors and exposure concentration. Aquat. Toxicol. 84, 236-246. https:// doi.org/10.1016/j.aquatox.2007.02.022.

Diepens, N.J., Van den Heuvel-Greve, M.J., Koelmans, A.A., 2015. Modeling of bioaccumulation in marine benthic invertebrates using a multispecies experimental approach. Environ. Sci. Technol. 49, 13575-13585. https://doi.org/10.1021/acs.est. 5b02500.

EFSA Panel on Contaminants in the Food Chain (CONTAM), 2016. Presence of microplastics and nanoplastics in food, with particular focus on seafood. EFSA J. 14. https://doi.org/10.2903/j.efsa.2016.4501.

Fabinyi, M., 2016. Sustainable seafood consumption in China. Mar. Policy 74, 85-87. https://doi.org/10.1016/j.marpol.2016.09.020.

FAO (Ed.), 2016. Contributing to Food Security and Nutrition for All. The state of world fisheries and aquaculture, Rome.

Fierens, T., Van Holderbeke, M., Standaert, A., Cornelis, C., Brochot, C., Ciffroy, P., Johansson, E., Bierkens, J., 2016. Multimedia \& PBPK modelling with MERLIN-Expo versus biomonitoring for assessing $\mathrm{Pb}$ exposure of pre-school children in a residential setting. Sci. Total Environ. 568, 785-793. https://doi.org/10.1016/j.scitotenv.2016. 03.194.

Gao, X., Chen, C.-T.A., 2012. Heavy metal pollution status in surface sediments of the coastal Bohai Bay. Water Res. 46, 1901-1911. https://doi.org/10.1016/j.watres. 2012.01.007.

Giubilato, E., Radomyski, A., Critto, A., Ciffroy, P., Brochot, C., Pizzol, L., Marcomini, A., 2016. Modelling ecological and human exposure to POPs in Venice lagoon. Part I application of MERLIN-Expo tool for integrated exposure assessment. Sci. Total Environ. https://doi.org/10.1016/j.scitotenv.2016.04.146.

Gobas, F.A.P.C., Pasternak, J.P., Lien, K., Duncan, R.K., 1998. Development and field validation of a multimedia exposure assessment model for waste load allocation in aquatic ecosystems: application to 2,3,7,8-tetrachlorodibenzo-p-dioxin and 2,3,7,8tetrachlorodibenzofuran in the Fraser River watershed. Environ. Sci. Technol. 32, 2442-2449. https://doi.org/10.1021/es980022.

Guo, B., Jiao, D., Wang, J., Lei, K., Lin, C., 2016. Trophic transfer of toxic elements in the estuarine invertebrate and fish food web of Daliao River, Liaodong Bay, China. Mar. Pollut. Bull. 113, 258-265. https://doi.org/10.1016/j.marpolbul.2016.09.031.

Harkell, L., 2018. China to drive more than half of global seafood consumption growth over next decade. Undercurrent News (Jan 12). https://www.undercurrentnews. com/2018/01/12/rabobank-china-to-drive-more-than-half-of-global-seafoodconsumption-growth-over-next-decade/.

Hendriks, A.J., 2007. The power of size: a meta-analysis reveals consistency of allometric regressions. Ecol. Model. 205, 196-208. https://doi.org/10.1016/j.ecolmodel.2007. 02.029.

Hendriks, A.J., Heikens, A., 2001. The power of size. 2. Rate constants and equilibrium ratios for accumulation of inorganic substances related to species weight. Environ. Toxicol. Chem. 20, 1421-1437. https://doi.org/10.1002/etc.5620200704.

Hendriks, A.J., van der Linde, A., Cornelissen, G., Sijm, D.T.H.M., 2001. The power of size. 1. Rate constants and equilibrium ratios for accumulation of organic substances related to octanol-water partition ratio and species weight. Environ. Toxicol. Chem. 20, 1399-1420. https://doi.org/10.1002/etc.5620200703.

Hu, S., Su, Z., Jiang, J., Huang, W., Liang, X., Hu, J., Chen, M., Cai, W., Wang, J., Zhang, X., 2016. Lead, cadmium pollution of seafood and human health risk assessment in the coastline of the southern China. Stoch. Env. Res. Risk A. 30, 1379-1386. https:// doi.org/10.1007/s00477-015-1139-9.

Koelmans, A.A., 2015. Modeling the role of microplastics in bioaccumulation of organic chemicals to marine aquatic organisms. A critical review. In: Bergmann, M., Gutow, L., Klages, M. (Eds.), Marine Anthropogenic Litter. Springer International Publishing, Cham, pp. 309-324. https://doi.org/10.1007/978-3-319-16510-3_11.

Li, X., Li, J., Wang, Y., Fu, L., Fu, Y., Li, B., Jiao, B., 2011. Aquaculture industry in China: current state, challenges, and outlook. Rev. Fish. Sci. 19, 187-200. https://doi.org/ $10.1080 / 10641262.2011 .573597$.

Liu, J.-L., Xu, X.-R., Ding, Z.-H., Peng, J.-X., Jin, M.-H., Wang, Y.-S., Hong, Y.-G., Yue, W.Z., 2015. Heavy metals in wild marine fish from South China Sea: levels, tissue- and species-specific accumulation and potential risk to humans. Ecotoxicology 24, 1583-1592. https://doi.org/10.1007/s10646-015-1451-7.

Luoma, S.N., Presser, T.S., 2000. Forecasting selenium discharges to the San Francisco Bay-Delta Estuary: ecological effects of a proposed San Luis Drain extension. US Department of the Interior, US Geological Survey.

Mathews, T., Fisher, N.S., 2008. Evaluating the trophic transfer of cadmium, polonium, and methylmercury in an estuarine food chain. Environ. Toxicol. Chem. 27, 1093-1101.

McGeer, J.C., Brix, K.V., Skeaff, J.M., Deforest, D.K., Brigham, S.I., Adams, W.J., Green, A., 2003. Inverse relationship between bioconcentration factor and exposure concentration for metals: implications for hazard assessment of metals in the aquatic environment. Environ. Toxicol. Chem. 22, 1017-1037. https://doi.org/10.1002/etc. 5620220509.

Men, B., He, M., Tan, L., Lin, C., 2014. Distributions of polychlorinated biphenyls in the Daliao River estuary of Liaodong Bay, Bohai Sea (China). Mar. Pollut. Bull. 78, 77-84. https://doi.org/10.1016/j.marpolbul.2013.11.005.

Morris, M.D., 1991. Factorial sampling plans for preliminary computational experiments. Technometrics 33, 161-174.

OECD/FAO, 2017. OECD-FAO Agricultural Outlook 2017-2026. OECD Publishing, Paris. https://doi.org/10.1787/agr_outlook-2017-en.

Oksman, O., 2016. Fish for dinner? Your seafood might come with a side of plastic, Guardian. (August 31). https://www.theguardian.com/lifeandstyle/2016/aug/31/ fish-plastic-pollution-ocean-environment-seafood.

Pan, K., Wang, W.-X., 2012. Trace metal contamination in estuarine and coastal environments in China. Sci. Total Environ. 421-422, 3-16. https://doi.org/10.1016/j. scitotenv.2011.03.013. 
Peng, J., Wang, J., Cai, L., 2017. Current understanding of microplastics in the environment: occurrence, fate, risks, and what we should do: current understanding of microplastics and what we should do. Integr. Environ. Assess. Manag. 13, 476-482. https://doi.org/10.1002/ieam.1912.

Radomyski, A., Giubilato, E., Ciffroy, P., Critto, A., Brochot, C., Marcomini, A., 2016. Modelling ecological and human exposure to POPs in Venice lagoon - part II: quantitative uncertainty and sensitivity analysis in coupled exposure models. Sci. Total Environ. 569-570, 1635-1649. https://doi.org/10.1016/j.scitotenv.2016.07. 057.

Radomyski, A., Giubilato, E., Suciu, N.A., Critto, A., Ciffroy, P., 2018. Modelling bioaccumulation in aquatic organisms and in mammals. In: Ciffroy, P., Tediosi, A., Capri, E. (Eds.), Modelling the Fate of Chemicals in the Environment and the Human Body. Springer International Publishing, Cham, pp. 191-213. https://doi.org/10.1007/ 978-3-319-59502-3_9.

Reinfelder, J.R., Fisher, N.S., Luoma, S.N., Nichols, J.W., Wang, W.-X., 1998. Trace element trophic transfer in aquatic organisms: a critique of the kinetic model approach. Sci. Total Environ. 219, 117-135. https://doi.org/10.1016/S0048-9697(98)00225-3.

Rodríguez-Hernández, Á., Camacho, M., Henríquez-Hernández, L.A., Boada, L.D., RuizSuárez, N., Valerón, P.F., Almeida González, M., Zaccaroni, A., Zumbado, M., Luzardo, O.P., 2016. Assessment of human health hazards associated with the dietary exposure to organic and inorganic contaminants through the consumption of fishery products in Spain. Sci. Total Environ. 557-558, 808-818. https://doi.org/10.1016/j. scitotenv.2016.03.035.

Saltelli, A., Tarantola, S., Chan, K.P.-S., 1999. A quantitative model-independent method for global sensitivity analysis of model output. Technometrics 41, 39-56. https://doi. org/10.1080/00401706.1999.10485594.

Szefer, P., 2013. Safety assessment of seafood with respect to chemical pollutants in European Seas. Oceanol. Hydrobiol. Stud. 42. https://doi.org/10.2478/s13545-0130063-1.

Tanaka, T., Capri, E., Ciffroy, P., 2011. Probabilistic and Full-Chain Risk Assessment of the Chemical Accumulation on Human Body Using an Integrated Modeling Tool.
Goliardica Pavese Pavia.

Thomann, R.V., Mahony, J.D., Mueller, R., 1995. Steady-state model of biota sediment accumulation factor for metals in two marine bivalves. Environ. Toxicol. Chem. 14 1989-1998. https://doi.org/10.1002/etc.5620141121.

Tong, Y., Wang, M., Bu, X., Guo, X., Lin, Y., Lin, H., Li, J., Zhang, W., Wang, X., 2017. Mercury concentrations in China's coastal waters and implications for fish consumption by vulnerable populations. Environ. Pollut. 231, 396-405. https://doi.org/ 10.1016/j.envpol.2017.08.030.

Veltman, K., McKone, T.E., Huijbregts, M.A.J., Hendriks, A.J., 2009. Bioaccumulation potential of air contaminants: combining biological allometry, chemical equilibrium and mass-balances to predict accumulation of air pollutants in various mammals. Toxicol. Appl. Pharmacol. 238, 47-55. https://doi.org/10.1016/j.taap.2009.04.012.

Wan, Y., Jin, X.H., Hu, J.Y., Jin, F., 2007. Trophic dilution of polycyclic aromatic hydrocarbons (PAHs) in a marine food web from Bohai Bay, North China. Environ. Sci. Technol. 41, 3109-3114.

Wan, Y., Hu, J.Y., Zhang, K., An, L.H., 2008. Trophodynamics of Polybrominated Diphenyl Ethers in the Marine Food Web of Bohai Bay, North China. Environ. Sci. Technol. 42, 1078-1083.

Wang, W.-X., 2011. Incorporating exposure into aquatic toxicological studies: an imperative. Aquat. Toxicol. 105, 9-15. https://doi.org/10.1016/j.aquatox.2011.05. 016.

Webster, E.M., Ellis, D.A., 2012. Estimating chemical biotransformation rates from food web concentrations. Chemosphere 87, 404-412. https://doi.org/10.1016/j. chemosphere.2011.12.036.

Williams, J.J., Dutton, J., Chen, C.Y., Fisher, N.S., 2010. Metal (As, Cd, $\mathrm{Hg}$, and $\mathrm{CH}_{3} \mathrm{Hg}$ ) bioaccumulation from water and food by the benthic amphipod Leptocheirus plumulosus. Environ. Toxicol. Chem. https://doi.org/10.1002/etc.207. (n/a-n/a).

Xu, B., Yang, X., Gu, Z., Zhang, Y., Chen, Y., Lv, Y., 2009. The trend and extent of heavy metal accumulation over last one hundred years in the Liaodong Bay, China. Chemosphere 75, 442-446. https://doi.org/10.1016/j.chemosphere.2008.12.067. 